\title{
Synthesis Of Some Substituted 1,2,5-Oxadiazino [2- 3,b] Quinazoline And Some 1,3-Oxazole Derivatives
}

\author{
Yassir S. Mohamad \\ Chemistry Department / College of Education \\ University of Mosul
}

Received

13 / 08 / 2012
Accepted

$18 / 10 / 2012$

\section{الخلاصة}

تم في هذا البحث تحضير عدد من معوضات 5,2,1-اوكسادايازينو [b,3-2] كوينازولين وعدد من معوضات 3,1- اوكسازول حيث نم مفاعلة حامض اميني (ألاثين او الفالين) مع كلوريد البنزويل في وسط قاعدي لأعطاء N- بنزوايل الانين او فالين (2,1), ثم ثم

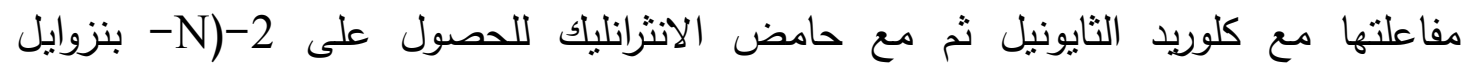
معوضات الميثايل امين 1,3- بنزواوكسازون -4- اون (4,3), ثم تفاعله مع هيدروكسيل امين النيد هيدروكلوريد في الايثنانول المطلق للحصول على مركبات N)2- بنزوايل معوضات ميثايل امين)-3- هيدروكسي كوينازولين -4- اون (6,5) ثم مفاعلته مع خامس كلوريد الفسفور

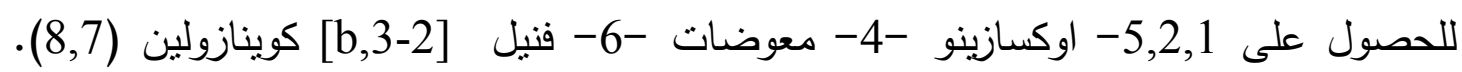
كما تم مفاعلة المركبات (4,3) مع الهيدروكسيل امين هيدروكلوريد في البريدين للحصول مباشرة

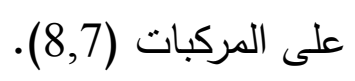

تم استرة N- بنزوايل الانين او فالين (2,1) بمفاعلته مع كلوريد الثايونيل في الكحول

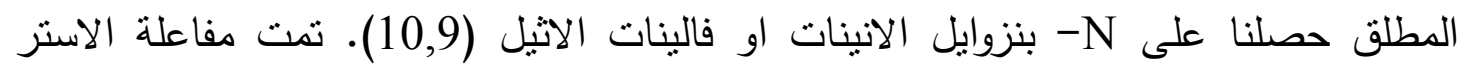

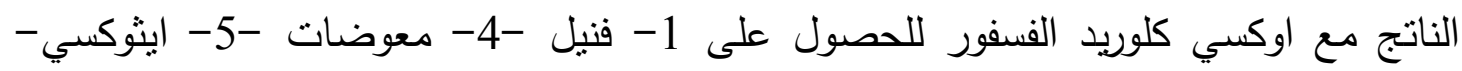
3,1 - اوكسازول (12,11).

شخصت تراكيب المركبات المحضرة بطيف IR و UV وبالطرق الفيزياوية.

\section{ABSTRACT}

In this paper the synthesis of some 1,2,5- oxadiazino [2-3,b] quinazoline and some substituted 1,3- oxazole are reported, alanine and valine were reacted with benzoyle chloride in sodium hydroxide solution to give $\mathrm{N}$ - benzoyle alanine or valine $(1,2)$, which was treated with 
thionyl chloride then with anthranilic acid to give 2-(N- benzoyle substituted methyl amine)-1,3- benzoxazine -4- one $(3,4)$, the resultant substituted benzoxazine were converted to 2-(N- benzoyl substituted) - 3hydroxyl quinazoline -4 - one $(5,6)$ by their reaction with hydroxyl amine hydrochloride in abs. ethanol, and the resultant substituted quinazoline reacted with phosphorous pentachloride to obtain the 4- substituted -6phenyl -1,2,5- oxadiazino [2-3,b] quinazoline $(7,8)$, also reaction of 2-(Nbenzoyl substituted methyl amine)-1,3- benzoxazine -4- one $(3,4)$ with hydroxyl amine hydrochloride in pyridine afforded 4- substituted -6phenyl - 1,2,5- oxadiazino [2-3,b] quinazoline $(7,8)$.

Reaction of the N- benzoyle alanine or valine $(1,2)$ with thionyl chloride in abs. ethanol to give N-benzoyl ethyl alanine or valine $(9,10)$ and when treated the ester with phosphorous oxychlorid gave 1- phenyl4- substituted -5- ethoxy -1,3- oxazole $(11,12)$.

The structure of the synthesis compounds were confirmed by IR, UV. Spectra and physical means.

\section{Introduction}

The family of hetrocyclic compound containing atom of nitrogen are an important class of compound in medical chemistry. There has been considerable interest in the development of preparative method for the production of quinazolines ${ }^{(1)}$.

Quinazoline and its derivatives are a class of hetroaromatic compound that have drawn much attention because of their biological and pharmaceutical activities including a wide range of antitumor activity ${ }^{(2)}$, anti- inflammatory, anti- allergic agents ${ }^{(3)}$, anticancer ${ }^{(4,5)}$, sperific, sedative and tranquilizing ${ }^{(6)}$.

There are many method to synthesis of quinazolines derivative, for example, the most commn synthesis of 4- quinazolones is a reaction of anthranilic acid with formamide at $120^{\circ} \mathrm{C}$, these reaction was called Niementowski reaction ${ }^{(7)}$.

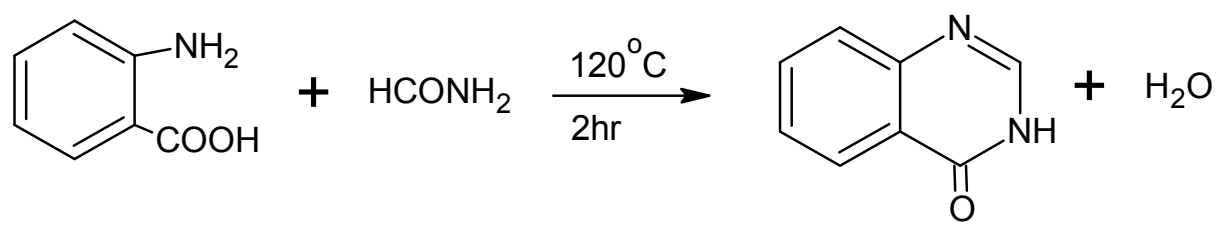

1,3- Oxazole derivatives like oxazolones exhibited promising photophysical and photochemical activities, so they are used semiconductor divices such as electrophotographic photoreceptors and in non - linear optical materials ${ }^{(8)}$.

There is many method to synthesis of 1,3-oxazoles derivatives for example the reaction below ${ }^{(9)}$.

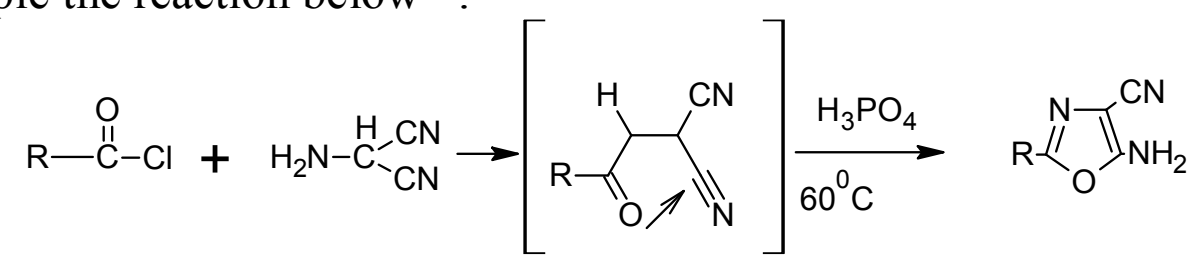




\section{Experimental}

The melting points were measured on an electro thermal 9300 engineering LTD and are uncorrected, IR spectrum were recorded on infrared spectrophotometer model tensor 27, Bruker Co., Germany, using $\mathrm{KBr}$ discs. The U.V spectrum were recorded on UV-Visible Shimadzu 1601 spectrophotometer using ethanol as a solvent. All chemicals were purchased from Fluka and BDH chemical Ltd.

\section{$\mathrm{N}$ - benzoyle alanine or valine $(1,2)^{(\mathbf{1 0})}$}

$(0.02 \mathrm{~mol})$ of alanine or valine in $(20 \mathrm{ml})$ of $1.0 \mathrm{~N}$ of sodium hydroxide was cooled at $(0-5) \mathrm{C}^{\mathrm{o}}$ and the cold solution was added drop wise to a solution of $(0.02 \mathrm{~mol}, 2 \mathrm{ml})$ of benzoyl chloride in $(30 \mathrm{ml})$ of dichloromethane. with continuous stirring for an additional of two hours. The aqueous layer was separated and acidified with $2 \mathrm{~N}$ hydrochloric acid. The solid product was filtrated and washed with water to gave the required compound table(1).

\section{2(N- benzoyl substituted methyl amine) 1,3 -Benzoxazin-4- one $(3,4)^{(11)}$}

Compound $(1,2),(0.1 \mathrm{~mol})$ and thionyl chloride $(11.8 \mathrm{~g}, 0.1 \mathrm{~mol})$ were mixed together and gently warmed for 2 hour, followed by the addition of anthranilic acid $(1.37,0.01 \mathrm{~mol})$ in $(50 \mathrm{ml})$ of dry benzene with continuous stirring. After complete addition, the reaction mixture was refluxed for additional one hour. Cooled and the solvent was then evaporated under reduced pressure, recrystallization of the residue from ethanol- water to gave the required products table (1 and 2).

\section{2(N-benzoyl substituted methyl amine) Quinazoline-4-one $(5,6)^{(12)}$.}

A mixture of (3 or 4) $(0.004 \mathrm{~mol})$, hydroxylamine hydrochloride $(1.04 \mathrm{~g}, 0.015 \mathrm{~mol})$, and anhydrous sodium acetate $(1.5 \mathrm{~g})$ in abs. ethanol $(50 \mathrm{ml})$ was refluxed for 8 hour. The reaction mixture was poured into water, stirred for $30 \mathrm{~min}$. and then filtered off. The deposited product was dried and recrystallized from ethanol-ether to gave the required products table (1 and 2).

\section{4-substituted-6- phenyl-1,2,5-Oxadiazino[2-3,b]Quinazoline $(\mathbf{7 , 8})^{(13)}$.}

Compound (5 or 6) $(0.01 \mathrm{~mol})$ and phosphorous pentachloride $(2.08 \mathrm{~g}, 0.01 \mathrm{~mol})$ were mixed together under unhydrous condition, the reaction mixture was heated for $\left(30 \mathrm{~min}\right.$.) at $\left(110^{\circ} \mathrm{C}\right)$, then the reaction temperature was raised to $\left(160^{\circ} \mathrm{C}\right)$ until the evolution of hydrogen chloride ceased about ( 0.5 hour). distillation of the resulted phosphorous oxychlorid under reduced pressure gave crude product washed with water and recrystallized from dioxane to gave the required products table (1 and 2). 
4- substituted-6- phenyl-1,2,5-Oxadiazino[2-3,b] Quinazoline (7,8) from $(3,4)^{(12)}$.

A solution of (3 or 4$)(0.004 \mathrm{~mol})$ and hydroxylamine hydrochloride $(1.04 \mathrm{~g}, 0.015 \mathrm{~mol})$ in pyridine $(30 \mathrm{ml})$ was refluxed for (16hour). The reaction mixture was cooled and poured onto a crushed ice/ $\mathrm{HCl}$ mixture. The solid that separated was filtered off, washed with water, dried and then recrystallized from dioxane to gave the required products table (1 and 2).

\section{$\mathrm{N}$-benzoyl ethyl alaninate or valinate $(9,10)^{(14)}$.}

Ethanol abs. $(100 \mathrm{ml})$ was added drop wise to a solution of $(0.1 \mathrm{~mol})$ of (1 or 2) and thionyl chloride $(9.5 \mathrm{ml}, 0.1 \mathrm{~mol})$, and the mixture cooled to $\left(0-5^{\circ} \mathrm{C}\right)$ with stirring from $\left(30 \mathrm{~min}\right.$.), then refluxed for (2hours) at $\left(50^{\circ} \mathrm{C}\right)$ until the solution became clear, then evaporated under reduced pressure to half volume, after that the solution poured into cooled water, the bottom layer separated with separation funnel to gave the required products Table (1 and 2).

\section{2-phenyl -4- substituted -5- ethoxy $-1,3$ - oxazole $(11,12)^{(15)}$.}

To $(0.01 \mathrm{~mol})$ of $(9$ or 10$)$ soluble in $(25 \mathrm{ml})$ benzene was added $(20 \mathrm{ml})$ of phosphorous oxychloride and refluxed for (4hours). The reaction mixture was treated with ice- water and extracted with methylene chloride and dried, the solid product was recrystallized from etherpetroleum ether to gave the required products table(1 and 2).

\section{Results and Discussion}

Quinazolin derivatives were synthesized from alanine and valine by their reaction with benzoyl chloride which afforded N-benzoyl alanine or valine $(1,2)$. Scheme (1). The IR spectra of $(1,2)$ show absorption at $1725,1726 \mathrm{~cm}^{-1}(\mathrm{C}=\mathrm{O})$ and $3370,3306 \mathrm{~cm}^{-1}(\mathrm{~N}-\mathrm{H}), \lambda_{\max } 248,246 \mathrm{~nm}$. Compound $(1,2)$ were treated with thionyl chloride and then with anthranilic acid to give benzoxazin derivatives $(3,4)$. The absorption band of the $(\mathrm{C}=\mathrm{N})$ group appears in the $1603,1604 \mathrm{~cm}^{-1}$ and the band at 1723 , $1718 \mathrm{~cm}^{-}$due to $(\mathrm{C}=\mathrm{O})$ ester. The benzoxazin derivative $(3,4)$ treated with hydroxylamine hydrochloride in abs. ethanol to give quinazoline derivative $(5,6)$ in the IR spectra the absorption band show absence of $(\mathrm{C}=\mathrm{O})$ ester, and $(\mathrm{C}=\mathrm{O})$ amide appears in $1684,1677 \mathrm{~cm}^{-1}, \lambda_{\max } 410$, $374 \mathrm{~nm}$.

Quinazoline derivative $(5,6)$ treated with phosphorous pentachloride to give 4- substituted -6- phenyl oxadiazino [2-3,b] quinazoline $(7,8)$ the absorption band of the $(7,8)$ show the absence of $(\mathrm{N}$ $\mathrm{H})$ and decrease in $\lambda_{\max }$ to $360,365 \mathrm{~nm}$. Also benzoxazine derivative $(3,4)$ were converted to quinazoline derivatives $(7,8)$ by their reaction with hydroxylamine hydrochlorid in pyridine, the IR spectra show absence of $(\mathrm{C}=\mathrm{O})$ ester absorption.

Compound $(1,2)$ were treated with thionyl chloride in abs. ethanol to give N-benzoyl ethyl alaninate or valinate $(9,10)$, the absorbtion band of the $(\mathrm{C}=\mathrm{O})$ ester appears in $1750,1719 \mathrm{~cm}^{-1}, \lambda_{\max } 383,400 \mathrm{~nm}$. The esters were treated with phosphorous oxychloride to give $(11,12)$, the IR spectra 
show appear of $(\mathrm{C}=\mathrm{N})$ at $1642,1626 \mathrm{~cm}^{-1}, \lambda_{\max } 415,425 \mathrm{~nm}$. Table (1 and 2).

The proposed mechanism for the conversion of compound $(3,4)$ to $(7,8)$ (rout A and B) as follows.

$$
\text { route } A
$$

$$
\text { (3,4) }
$$

route $B$
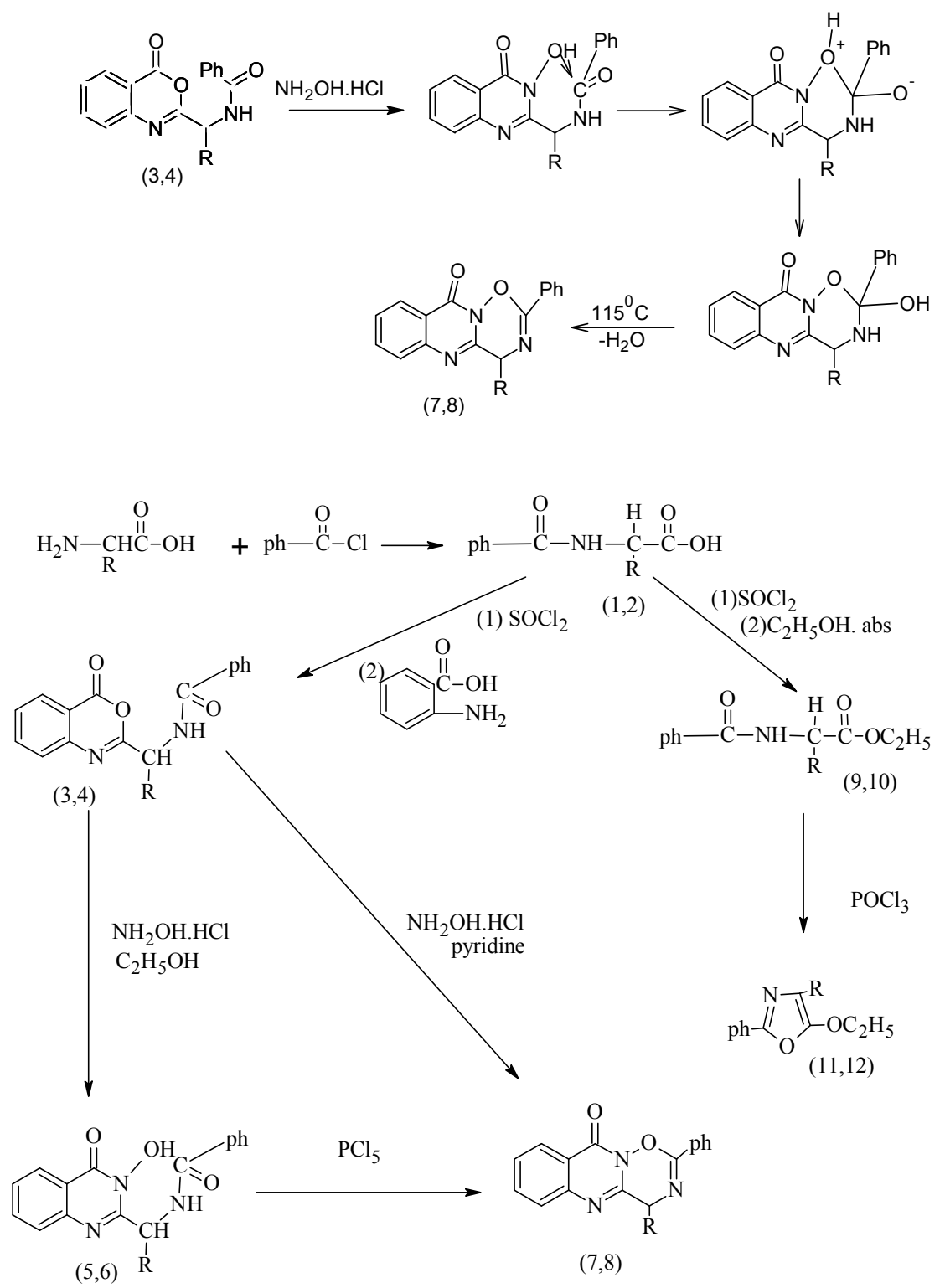
Scheme(1)

Table (1): UV and IR Spectra Data of Synthesised Compound

\begin{tabular}{|c|c|c|c|c|c|c|c|c|}
\hline \multirow{2}{*}{$\begin{array}{c}\text { Com. } \\
\text { No. }\end{array}$} & \multirow{2}{*}{ structure } & \multirow{2}{*}{$\begin{array}{c}\mathrm{U.V} \\
\lambda \text { max } \\
\text { in } \\
\text { ethanol }\end{array}$} & \multicolumn{6}{|c|}{$\begin{array}{c}\text { I.R v } \\
\mathrm{cm}^{-1}(\mathrm{KBr})\end{array}$} \\
\hline & & & OH & $\mathbf{C}=\mathbf{N}$ & $\begin{array}{l}\mathrm{C}=\mathrm{O} \\
\text { acid }\end{array}$ & $\begin{array}{l}C=\mathbf{O} \\
\text { ester }\end{array}$ & $\begin{array}{l}\mathrm{C}=\mathrm{O} \\
\text { amid }\end{array}$ & N-H \\
\hline 1 & 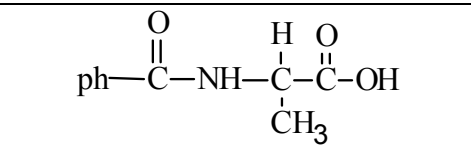 & 248 & 3255 & - & 1725 & - & 1627 & 3370 \\
\hline 2 & $\begin{array}{c}\mathrm{O} \\
\mathrm{ph}-\stackrel{\mathrm{I}}{\mathrm{C}}-\mathrm{N} \mathrm{H}-\stackrel{\mathrm{I}}{\mathrm{C}}-\stackrel{\mathrm{I}}{\mathrm{C}}-\mathrm{OH} \\
\left(\mathrm{H}_{3} \mathrm{C}\right)_{2} \mathrm{HC}^{\mathrm{I}}\end{array}$ & 246 & 3240 & - & 1726 & - & 1642 & 3306 \\
\hline 3 & $\begin{array}{l}\mathrm{CH} \\
\stackrel{\mathrm{CH}}{\mathrm{C}}{ }_{3} \\
\end{array}$ & 395 & - & 1603 & - & 1723 & 1686 & 3434 \\
\hline 4 & $\begin{array}{l}\mathrm{CH}^{-\stackrel{1}{\mathrm{~N}} \mathrm{H}} \\
\mathrm{C} H\left(\mathrm{CH}_{3}\right)_{2}\end{array}$ & 356 & - & 1604 & - & 1718 & 1681 & 3420 \\
\hline 5 & & 410 & 3150 & 1604 & & - & 1678 & 3432 \\
\hline 6 & & 374 & 3292 & 1604 & & - & 1677 & 3423 \\
\hline 7 & & 360 & - & 1604 & & - & 1680 & - \\
\hline 8 & & 365 & - & 1603 & & - & 1678 & - \\
\hline 9 & 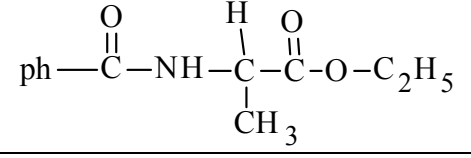 & 383 & - & - & & 1750 & 1641 & 3346 \\
\hline 10 & 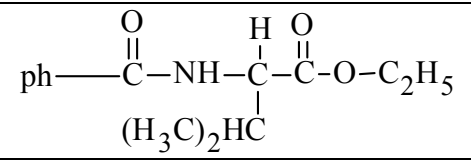 & 400 & - & - & & 1719 & 1667 & 3375 \\
\hline 11 & $\mathrm{ph} \underset{\mathrm{O}}{\mathrm{N}} \prod_{-\mathrm{OC}_{2} \mathrm{H}_{5}}^{\mathrm{CH}}$ & 415 & - & 1642 & & - & - & - \\
\hline 12 & $\mathrm{ph}-\prod_{\mathrm{O}}^{\mathrm{N}} \prod_{-\mathrm{OC}_{2} \mathrm{H}_{5}}^{\mathrm{CH}\left(\mathrm{CH}_{3}\right)_{2}}$ & 425 & - & 1626 & & - & - & - \\
\hline
\end{tabular}


Table(2): physical properties of compound

\begin{tabular}{|c|c|c|c|c|}
\hline Comp. No. & Yield $(\%)$ & M.P. $\left({ }^{\circ} \mathrm{C}\right)$ & B.P. $\left({ }^{\circ} \mathrm{C}\right)$ & Color \\
\hline 1 & 85 & $106-108$ & - & White \\
\hline 2 & 90 & $85-87$ & - & white \\
\hline 3 & 75 & $163-165$ & - & Brown- yellow \\
\hline 4 & 77 & $140-142$ & - & Brown \\
\hline 5 & 73 & $238-236$ & - & Brown \\
\hline 6 & 62 & $188-186$ & - & yellow \\
\hline 7 & 85 & $197-199$ & - & Brown \\
\hline 8 & 81 & $179-181$ & - & Brown \\
\hline 9 & 61 & - & $85-87$ & Yellow \\
\hline 10 & 70 & - & $97-99$ & red \\
\hline 11 & 45 & $339 \mathrm{~d}$ & - & yellow \\
\hline 12 & 60 & $345 \mathrm{~d}$ & - & Yellow \\
\hline
\end{tabular}

\section{References}

1) Kaur R., Bansal M. and Kaur B., Chemical Sciences Journal, V. CSJ- 18:p.1-9 (2011).

2) Sondip K., Mathew P., Maritzar Q., Ande B. and Georgr R., Arkivoic, (ii)33-42 (2008).

3) Mani P. C., Raghu A. R., Narsaiah B. and Bhagawan M. R., J. chem. Sci., 6(3):1119-1146 (2008).

4) Mahmoud R. M., Manal M. and Fatma S.M., European Journal of chemistry, 2(3):404-409 (2011).

5) Adel S. E., Mohamad A. A. and Alao A., European Journal of Medicinal Chemistry, 45:4188-4198 (2010).

6) Theivendren P. S., PalaniraJan V. K., Research in Pharmacy, 1(1): 1- 21 (2011).

7) Robert C. E., "Heterocyclic Compound". University of Michigan, Volum 6:P.331 (1957).

8) Suman B., Minaxi S. and Sunil K., International Journal of Chem Tech Research, Vol.3, No.3: p.1102-1118 (2011).

9) Carreiras C. M., Ana E., Catarina D., Brito M. A., Dora B., Marco J. and Elena G. S., Hetrocycles, Vol.71, No.10 (2007).

10) Schiketanz I., Draghici C., Sarament I. and Balaban A. T., Arkivoc, (ii) 64-72 (2002).

11) Essa M. A., M. Sc. Thesis, College of Education University of Mosul (2000).

12) Mahmoud R. M. and Hamed A. Y., Synthetic Communications, 40: 1516- 1529 (2010).

13) Cookson R. C., J. Chem. Soc., 643 (1953).

14) Kawthar H. Y., PhD Thesis, College of Education, University of Mosul (2000).

15) Schiketanz I., Draghici C., Sarament I. and Balaban A. T., Arkivoc, (ii): 64-72 (2002). 